\title{
PERAN CORPORATE GOVERNANCE DAN KARAKTERISTIK MANAJER DALAM MANAJEMEN LABA
}

\author{
SEPTIVIANI BHAYANGKARI \\ LAILAH FUJIANTI \\ TRI ASTUTI \\ Universitas Pancasila, Jl. Raya Lenteng Agung No.56-80, RT.1/RW.3, Srengseng Sawah, Kec. Jagakarsa, \\ Jakarta 12640, Indonesia \\ lailahfujianti@gmail.com
}

\begin{abstract}
This research with an objective to verify the correlations between corporate governance, manager characteristics and company size to the profit. The corporate governance which includes board of commissioners, audit committee and board of directors. Whereas manager characteristics that's being used is managerial educations. The number of samples that's in use are 14 industrial and chemical companies which shares are registered in Bursa Efek Indonesia in the period of 2015-2017. Based on the research results, shows that the board of commissioners variable is significantly effecting the profit managements. This proves that board commissioners are adequate to subdue the actions of earnings management. While audit committee, board of commissioners, managerial educations and company size to the profit doesn't show same significant effects to earnings management as board commissioners does.
\end{abstract}

Keywords: Corporate governance, manager characteristics, firm size, earnings management

Abstrak: Tujuan penelitian adalah untuk memverifikasi korelasi antara tata kelola perusahaan, karakteristik manajer dan ukuran perusahaan terhadap laba. Tata kelola perusahaan yang meliputi dewan komisaris, komite audit dan dewan direksi. Sedangkan karakteristik manajer yang digunakan adalah pendidikan manajerial. Jumlah sampel yang digunakan adalah 14 perusahaan industri dan kimia yang sahamnya terdaftar di Bursa Efek Indonesia pada periode 2015-2017. Berdasarkan hasil penelitian, menunjukkan bahwa variabel dewan komisaris berpengaruh signifikan terhadap manajemen laba. Ini membuktikan bahwa dewan komisaris memadai untuk menundukkan tindakan manajemen laba. Sementara komite audit, dewan komisaris, pendidikan manajerial dan ukuran perusahaan terhadap laba tidak menunjukkan pengaruh signifikan yang sama terhadap manajemen laba seperti halnya dewan komisaris.

Kata kunci: Tata kelola perusahaan, karakteristik manajer, ukuran perusahaan, manajemen laba

\section{PENDAHULUAN}

Laporan keuangan merupakan sumber informasi yang digunakan untuk menilai posisi keuangan dan kinerja sebuah perusahaan. Menurut Yogi dan Damayanti (2016) investor cenderung hanya memerhatikan angka laba yang tersaji dalam laporan keuangan tanpa memerhatikan proses yang digunakan untuk mencapai tingkat laba tersebut. Dalam menyusun sebuah laporan keuangan, manajemen diwajibkan untuk menetapkan standar akuntansi keuangan yang berlaku. Namun manajemen perusahaan memiliki 
kekuasaaan untuk menentukan penilaian atas kegiatan ekonomi yang dilakukan perusahaan. Sehingga akan timbul perbedaan antara standar yang berlaku dengan praktik yang terjadi di perusahaan. Dari perbedaan yang timbul menyebabkan manajemen untuk memodifikasi laporan keuangan agar dapat disajikan laba sesuai dengan yang diingingkan oleh berbagai pihak. Aktivitas manajemen diatas disebut Manajemen Laba.

Konflik keagenaan dapat mengakibatkan adanya sifat manajemen melaporkan laba secara oportunitis untuk memaksimalkan kepentingan pribadinya. Menurut Rachmawati dan Traitmoko (2007) Jika ini dilakukan oleh manajemen, maka akan mengakibatkan rendahnya kualitas laba. Pihak manajemen yang mempunyai kepentingan tertentu akan cenderung menyusun laporan laba sesuai dengan tujuan yang diharapkan, bukan semata-mata demi kepentingan prinsipal. Untuk mengurangi terjadinya tindakan Manajemen Laba maka upaya yang dapat dilakukan antara lain dengan membangun sistem pengawasan dan pengendalian yang lebih efektif, karena akan mendorong terciptanya keadilan, transparansi, akuntabilitas dan responsibilitas dalam pengelolaan laporan keuangan sebuah perusahaan. Menurut Wardhani dan Joseph (dalam Yogi dan Damayanti, 2016). Sistem ini dapat dilakukan dengan cara menerapkan tata kelola perusahaan atau Corporate Governance (CG). CG dapat memberi keyakinan untuk para pengguna informasi keuangan bahwa laporan keuangan yang diinformasikan oleh perusahaan adalah akurat.

Praktik CG memiliki beberapa komponen seperti halnya dewan komisaris, komite audit, dan dewan direksi. Fungsi dewan komisaris sesuai dengan yang dinyatakan dalam National Code for Corporate Governance adalah memastikan bahwa perusahaan telah melakukan tanggung jawab sosial dan mempertimbangkan kepentingan berbagai stakeholder perusahaan sebaik memonitor efektifitas pelaksanaan CG. Dewan Komisaris ditugaskan dan diberi tanggung jawab dalam pengawasan kualitas informasi yang terkandung dalam lapoan keuangan. Hal ini penting karena adanya kepentingan manajemen untuk melakukan Manajemen Laba yang memberikan dampak pada berkurangannya kepercayaan investor. Supaya dewan komisaris diizinkan untuk memiliki akses pada informasi perusahaan. Menurut NCCG Dewan komisaris tidak memiliki otoritas dalam perusahaan, maka dewan direksi bertanggung jawab untuk menyampaikan informasi terkait dengan perusahaan kepada dewan komisaris. Selain mensupervisi dan memberi nasihat kepada dewan direksi sesuai UU No. 1 tahun 1995, fungsi dewan komisaris yang lain National Code for Corporate Governance adalah memastikan bahwa perusahaan telah melakukan tanggung jawab sosial dan mempertimbangkan kepentingan berbagai stakeholder perusahaan sebaik memonitor efektifitas pelaksanaan CG.

Sesuai Kep. 29/PM/2004 komite audit adalah komite yang dibentuk oleh dewan komisaris untuk melakukan tugas pengawasan pengelolaan perusahaan. Keberadaan komite audit sangat penting bagi pengelolaan perusahaan. Dewan direksi merupakan pusat pengendali dalam perusahaan, dan dewan direksi juga merupakan penanggung jawab utama pada keberhasilan perusahaan secara jangka panjang. Terkait dalam teori agensi fungsi dewan direksi mempunyai peran dalam proses pengaturan kinerja perusahaan sehingga dewan direksi mengetahui seluruh informasi baik dan buruknya yang ada dalam perusahaan. Informasi tersebut disebut asimetri informasi dimana di dalamnya terdapat informasi yang sangat berharga apabila tidak digunakan dengan baik bisa merugikan perusahaan, informasi tersebut biasanya telah diketahui atau 
di dapat terlebih dahulu oleh para dewan direksi untuk menjalankan kegiatan perusahaan. Dengan demikian terciptalah suatu regulasi yang disebut CG yang berfungsi untuk mencegah tindakan dewan direksi yang menyimpang dari pelaksanaan kegiatan perusahaan dan diharapkan tidak terjadi Manajemen Laba sehingga perlu dilakukan kontrol yang ketat.

Devi dan Khoirudin (2016); Abbadi et al. (2016): Sari dan Putri (2014) menemukan ukuran dewan komisaris berpengaruh positif signifikan terhadap manajemen laba. Okougbo dan Okike (2015); Mariana et al. 2016 menunjukkan CG tidak berpengaruh terhadap manajemen laba. Dewan komisaris diharapkan dapat bertindak secara obyektif terlepas dari pengaruh berbagai pihak yang memiliki kepentingan yang berbeda dengan pihak lain. Hasil penelitian sebelum mengenai hubungan CG terhadap manajemen laba sangat beragam maka penelitian ini kembali akan membahas variabel tersebut dalam kaitannya dengan manajemen laba.

Faktor lain yang tidak kalah pentingnya dalam kaintannya dengan manajemen laba adalah manajer. Manajer berkepentingan untuk dilihat kinerjanya baik. Hal ini bertujuan untuk memperoleh keuntungan dalam bonus dan perpanjangan masa kontrak. Manajer dapat mempengaruh semua kebijakan dalam perusahaan termasuk dalam kebijakan, metode dan prosedur akuntansi yang diterima secara umum dalam upaya untuk menstabilkan laba yang diingingkan oleh pihak investor.

Faktor lain yang mempengaruhi praktik manajemen laba yaitu ukuran perusahaan. Terdapat dua pandangan tentang bentuk ukuran perusahan terhadap manajemen laba. Pandangan pertama, ukuran perusahaan yang kecil dianggap lebih banyak melakukan praktik manajemen laba daripada perusahaan besar. Hal ini dikarenakan perusahaan kecil cenderung ingin memperlihatkan kondisi perusahaan yang selalu berkinerja baik agar investor menanamkan modalnya pada perusahaan tersebut. Menurut Nasution dan Setiawan (2007) perusahaan yang besar lebih diperhatikan oleh masyarakat sehingga akan lebih berhati-hati dalam melakukan pelaporan keuangan sehingga berdampak perusahaan tersebut melaporkan kondisinya lebih akurat. Akan tetapi, pandangan kedua memandang ukuran perusahan mempunyai pengaruh positif terhadap manajemen laba. Joe dan Pagalung (2011) menyatakan bahwa perusahaanperusahaan besar yang memiliki biaya politik tinggi lebih cenderung memilih metode akuntansi untuk mengurangi laba yang dilaporkan dibandingkan perusahaanperusahaan kecil.

\section{Teori Keagenan}

Akar dari game theory adalah teori agency Menurut Scott (2012) dimana kepentingan agent dinyatakan bisa bertentangan dengan kepentingan principals. Pernyataan tersebut menjelaskan bahwa teori agensi terjadi ketika tujuan antara baik principal maupun agent saling bertolak belakang. Teori keagenan menyatakan bahwa praktik manajemen laba dipengaruhi oleh konflik kepentingan antara management (agent) dan pemilik (principal) yang tercetus ketika kedua belah pihak saling mengejar tujuannya masingmasing demi mempertahankan tingkat kemakmuran yang dikehendaki. Agensi teori memiliki asumsi bahwa masing-masing individu dalam hubungan keagenan semata-mata mementingkan kepentingan sendiri sehingga menimbulkan konflik kepentingan antara prinsipal dengan agen. 


\section{Manajemen Laba}

Sejalan dengan berkembangnya penelitian akuntansi keuangan dan keprilakuan saat ini ada beberapa definisi manajemen laba yang berbeda antara satu dengan lainnya sesuai dengan pemahaman dan penilaian orang yang mendefinisikan terhadap aktivitas pengelolaan dan pengaturan laba itu, antara lain: Menurut Sulistyanto (2014:6) Manajemen laba adalah upaya manajer perusahaan untuk mengintervensi atau mempengaruhi informasiinformasi dalam laporan keuangan dengan tujuan untuk mengelabui stakeholder yang ingin mengetahui kinerja dan kondisi perusahaan". Menurut Fahmi (2012:158) manajemen laba adalah "Suatu tindakan yang mengatur laba sesuai dengan yang dikehendaki oleh pihak tertentu atau terutama oleh manajemen perusahaan (company management). Manajemen laba adalah suatu penyusunan laporan keuangan yang sengaja dilakukan oleh manajemen yang ditunjukan pada pihak eksternal dengan cara meratakan, menaikan dan menurunkan laporan laba dengan tujuan menciptakan kinerja perusahaan agar terkesan lebih baik dari yang sebenarnya serta untuk memperoleh beberapa keuntungan pribadi

\section{Dewan Komisaris}

Xie et al. (2003) meneliti peran dewan komisaris dengan latar belakang bidang keuangan dalam mencegah manajemen laba. Dari penelitian ini diketahui makin sering dewan komisaris bertemu maka akrual kelolaan perusahaan makin kecil. Hal ini ditunjukkan dengan koefisien negatif yang signifikan. Menurut Putri et al. (2016) Dewan Komisaris merupakan mekanisme pengendalian intern tertinggi yang bertanggung jawab untuk memonitor tindakan manajemen puncak. Komposisi individu yang berkerja sebagai anggota dewan komisaris merupakan hal penting dalam memonitor aktivitas manajemen secara efektif. Hipotesis yang diajukan adalah: $\mathrm{H} 1$ : Dewan Komisaris berpengaruh terhadap manajemen laba.

\section{Komite Audit}

Sesuai dengan Kep. 29/PM/2004, komite audit adalah komite yang dibentuk oleh dewan komisaris untuk melakukan tugas pengawasan pengelolaan perusahaan. Keberadaan komite audit sangat penting bagi pengelolaan perusahaan. Komite audit merupakan komponen baru dalam sistem pengendalian perusahaan. Selain itu komite audit dianggap sebagai penghubung antara pemegang saham dan dewan komisaris dengan pihak manajemen dalam menangani masalah pengendalian. Berdasarkan Surat Edaran BEJ, SE-008/BEJ/12-2001, keanggotaan komite audit terdiri dari sekurang-kurangnya tiga orang termasuk ketua komite audit. Anggota komite ini yang berasal dari komisaris hanya sebanyak satu orang, anggota komite yang berasal dari komisaris tersebut merupakan komisaris independen perusahaan tercatat sekaligus menjadi ketua komite audit. Anggota lain yang bukan merupakan komisaris independen harus berasal dari pihak eksternal yang independen.

Menurut Yogi dan Damayanti (2016) Kualitas laporan keuangan sangat bergantung pada peran komite audit dalam mengawasi proses pelaporan keuangan oleh manajemen, sehingga dapat meningkatkan kredibilitas laporan keuangan. Dengan demikian, keberadaan komite audit diharapkan dapat meminimalisir tindakan manajemen laba. Hipotesis yang diajukan adalah:

H2: Komite Audit berpengaruh terhadap manajemen laba. 


\section{Dewan Direksi}

Menurut Aji (2012) Dewan direksi merupakan jumlah direksi yang dimiliki sebuah perusahaan yang bertugas untuk menentukan kebijakan yang akan diambil atau strategi perusahaan tersebut dalam jangka pendek maupun dalam jangka panjang. Indikator yang digunakan untuk mengukur dewan direksi adalah berapa jumlah dewan direksi yang dimiliki oleh sebuah perusaahaan dalam menjalankan kegiatan operasional perusahaan. Direksi bertanggungjawab dalam mengelola perusahaan, sedangkan jumlah ini disesuaikan dengan kompleksitas perusahaan namun tetap memperhatikan efektifitas dalam pengambilan keputusan secara cepat dan tepat.

Dewan Direksi bertugas dan bertanggung jawab dalam mengelola perusahaan dan dituntut untuk dapat melaksanakan tugasnya serta mampu mengambil keputusan sesuai dengan tugas dan wewenangnya. Dewan Direksi (DD) diukur atas jumlah dewan direksi yang dimiliki perusahaan (Hardikasari 2011, 56). Hipotesis yang diajukan adalah:

H3: Dewan Direksi berpengaruh terhadap manajemen laba

\section{Karakteristik Manajer}

Menurut Dewi et al. (2016) menyatakan bahwa tingkat pendidikan seorang karyawan dapat meningkatkan daya saing perusahaan dan memperbaiki kinerja perusahaan. Jadi dapat dikatakan bahwa sangat erat hubungan antara tingkat pendidikan dalam meningkatkan kinerja karyawan yang diharapkan perusahaan.
Tingkat pendidikan personel dalam perusahaan disebut sebagai modal intelektual. Modal intelektual memiliki peranan yang sangat penting dan strategis di dalam perusahaan. Moerdiyanto (2011) menyatakan bahwa ditinjau secara ekonomi, dengan modal intelektual memungkinkan manusia untuk meningkatkan produktivitasnya, memelihara dan mengembangkan sumber daya yang dimiliki serta membina motivasi yang tinggi dalam mencapai prestasi. Hipotesis yang diajukan adalah:

$\mathrm{H} 4$ : Manajer berpengaruh terhadap manajemen laba

\section{Ukuran Perusahaan}

Ukuran perusahaan dapat menjadi salah satu parameter untuk menilai besar kecilnya suatu perusahaan. Pendapat ini didukung oleh hasil penelitian yang dilakukan oleh Lufita dan Suryani (2018) yang menyatakan bahwa ukuran perusahaan yang diukur dengan logaritma dari jumlah total aset memiliki pengaruh positif. Sedangkan Susanto et al. (2019) menunjukkan bahwa ukuran perusahaan berpengaruh negatif terhadap manajemen laba. Hipotesis yang diajukan adalah:

H5: Ukuran Perusahaan berpengaruh terhadap manajemen laba

\section{METODA PENELITIAN}

Variabel meliputi manajemen laba, Dewan Komisaris, Komite Audit, Dewan Direksi dan manajer. 
Tabel 1 Pengukuran Variabel

\begin{tabular}{ll}
\hline Variabel & Pengukuran \\
\hline Manajemen Laba & $\frac{T A C t}{T A(t-1)}=a 1\left[\frac{1}{T A(t-1)}\right]+a 2\left[\frac{\Delta R E V t-\triangle R E C t}{T A(t-1)}\right]+a 3\left[\frac{P P E t}{T A(t-1)}\right]+\varepsilon$ \\
Dewan Komisaris & Jumlah hadir rapat dibagi jumlah jadwal rapat \\
Dewan Direksi & Jumlah anggota Dewan Direksi \\
Manajer & 1 bila pendidikan bisnis dan 0 jika bukan bisnis
\end{tabular}

Model persamaan regresi data panel yang digunakan sebagai berikut :

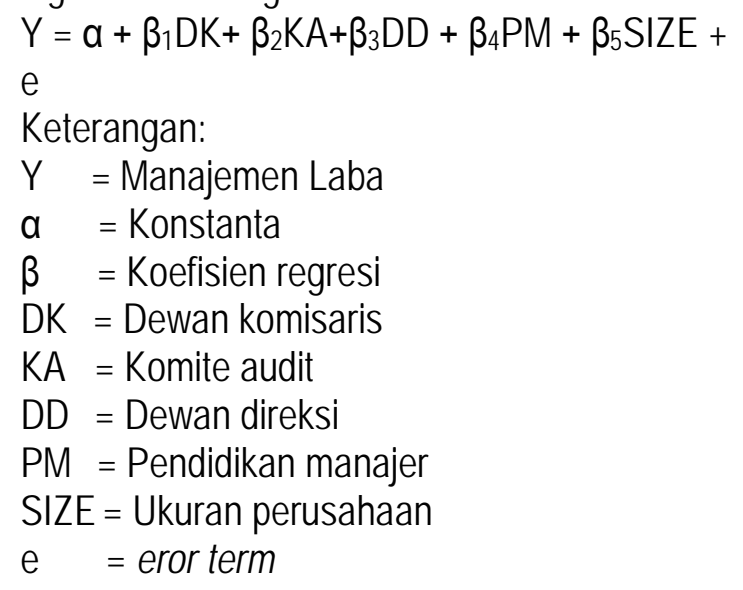

\section{HASIL DAN PEMBAHASAN}

Hasil uji hipotesa dengan model common effect menunjukkan $\mathrm{H} 1$ yang diterima. Penerimaan $\mathrm{H} 1$ diterima menandakan bahwa Dewan Komisaris berpengaruh signifikan. Hal ini berarti juga bahwa Dewan Komisaris (DK) berperan dalam manajemen laba. Variabel DK diukur dengan jumlah kehadiran rapat yang dijadwalkan untuk Dewan Komisaris. Hasil penelitian ini juga menunjukkan semakin banyak kehadiran DK dalam rapat koordinasi yang terjadwal meningkatkan informasi yang terkait dengan operasi perusahaan sehingga dapat melakukan kontrol yang efektif terhadap prilaku Dewan Direksi untuk melakukan tindakan opportunistik. Hasil ini sejalan dengan llyas et al. (2018). Oktavian et al. (2015) yang menyatakan bahwa komisaris berpengaruh negatif signifikan terhadap nilai discretionary accruals. Penurunan discretionary accruals memberikan sinyal adanya penurunan praktik manajemen laba, yang pada akhirnya dapat meningkatkan kualitas laba yang dilaporkan perusahaan.

DK yang memiliki berhubungan dengan kandungan informasi laba (Hidayanti et al. 2014). Peran DK dalam menjalankan fungsi pengawasan, komposisi dewan komisaris dapat mempengaruhi pihak manajemen dalam menyusun laporan keuangan sehingga diperoleh suatu laporan laba yang berkualitas. Informasi laba sering menjadi target rekayasa melalui tindakan oportunis manajemen. Hal ini dilakukan untuk memaksimumkan kepuasannya dari manajemen. Penetapan kebijakan akuntansi merupakan salah satu cara untuk praktik manajemen laba (Amperaningrum dan Sari 2013). 
Tabel 2 Uji Hipotesa

\begin{tabular}{|c|c|c|c|c|c|}
\hline Variable & Coefficient & Std. Error & t-Statistic & Prob & Keterangan \\
\hline C & $-0,202612$ & 0,225459 & $-0,898664$ & 0,3748 & \\
\hline DK & $-0,394428$ & 0,110612 & 3,565870 & 0,0010 & H1 Diterima \\
\hline KA & $-0,160712$ & 0,301827 & $-0,532464$ & 0,5977 & H2 Ditolak \\
\hline DD & $-0,048275$ & 0,051674 & $-0,934220$ & 0,3564 & H3 Ditolak \\
\hline PM & $-0,010106$ & 0,024978 & $-0,404606$ & 0,6882 & H4 Ditolak \\
\hline SIZE & $-0,002454$ & 0,005507 & $-0,445552$ & 0,6586 & H5 Ditolak \\
\hline
\end{tabular}

Hasil penelitian menunjukkan $\mathrm{H} 2$ ditolak. Penolakan ini berarti KA tidak berpengaruh signifikan terhadap manajemen laba. Hasil penelitian ini bertentangan konsep awal pembentukan KA. KA dibentuk untuk mengatasi berbagai skandal penyelewengan dan kekeliruan akibat berkurangnya pengawasan oleh direktur dan komisaris. Hasil penelitian ini mendukung hasil penelitian yang dilakukan oleh Lestari dan Murtanto (2018) yang menemukan aktivitas dari komite audit tidak berpengaruh terhadap manajemen laba. Namun hasil penelitian ini tidak sejalan dengan penelitian yang dilakukan oleh Khurnanto dan Syafruddin (2015) yang menyatakan efektivitas komite audit berpengaruh negatif terhadap manajemen laba. Hal ini disebabkan karena pembentukan komite audit yang memiliki keahlian di bidang keuangan yang seharusnya dapat membantu fungsi pengawasan dari dewan komisaris hanya bersifat mandatory saja agar dapat memenuhi peraturan yang berlaku.

DD merupakan organ perusahaan yang memiliki fungsi utama memberi perhatian terhadap penerapan corporate governace. DD bertanggung jawab, antara lain menetapkan tujuan strategis perusahaan, melakukan review pelaksanaan rencana strategis, memantau pengelolaan perusahaan, dan memastikan sistem pengendalian internal berjalan semestinya. Dewan direksi dalam suatu perusahaan akan menentukan kebijakan yang akan diambil atau strategi perusahaan tersebut secara jangka pendek maupun jangka panjang. Peran ini juga memungkinkan DD mempengaruhi manajemen laba. Akan tetapi hasil penelitian belum memberikan bukti mengenai hal tersebut karena hasil penelitian menunjukkan $\mathrm{H} 3$ ditolak. Penolakan ini berarti DD tidak berpengaruh signifikan terhadap manajemen laba.

Karakteristik manajer diproksikan dengan pendidikan manajer. Seiring dengan tantangan kehidupan global, pendidikan yang merupakan hal yang sangat penting karena pendidikan salah satu penentu mutu Sumber Daya Manusia. Keunggulan suatu bangsa tidak lagi ditandai dengan melimpahnya kekayaan alam, melainkan pada keunggulan Sumber Daya Manusia (SDM). Seorang manajer pun harus mempunyai pendidikan yang memadai dalam bidangnya supaya pada saat manager perusahaan melakukan Manajemen Laba tetap sesuai dengan metode dan prosedur akuntansi yang diterima dan telah diakui secara umum pada upaya untuk menstabilkan laba yang diingingkan oleh pihak investor. Sehingga manajer dalam melakukan Manajemen Laba menggunakan ilmu yang manajer punya dan sesuai dengan ketentuan dalam membuat laporan keuangan. Namun hasil penelitian ini belum mendukung pendapat di atas karena 
pengujian menunjukkan PM tidak berpengaruh. Hal ini faktor profitabilitas perusahaan. Manajer dapat berperan dalam manajemen laba jika profitabilitas yang dicapai perusahaan belum memadai karena berkeinginan menyelamatkan laporan kinerja di sudut pandang pemilik.

Hasil penelitian ini menemukan bahwa ukuran perusahaan tidak berpengaruh signifikan terhadap manajemen laba. Hasil penelitian ini mendukung temuan penelitian yang dilakukan Gunawan et al. (2015) yang menemukan bahwa ukuran perusahaan tidak berpengaruh dengan manajemen laba. Ukuran perusahaan tidak menjadi satu-satunya pertimbangan bagi para investor dalam pengambilan keputusan investasi. Tetapi, masih terdapat faktor-faktor lain yang lebih penting untuk dipertimbangkan dalam pengambilan keputusan investasi, seperti: tingkat keuntungan, prospek usaha perusahaan di masa yang akan datang, dan lainnya. Sifat investor Indonesia adalah spekulatif dan cenderung capital gain. Apalagi kondisi perusahaan-perusahaan di Indonesia, dengan besarnya asset yang dimiliki belum menjamin menghasilkan kinerja perusahaan yang baik.

\section{PENUTUP}

Simpulan penelitian menunjukkan bahwa dewan komisaris berpengaruh terhadap manajemen laba. Hal ini dikarenakan kurangnya pengawasan dewan komisaris terhadap manajemen maka terjadinya manajemen laba di dalam perusahaan. Komite audit tidak berpengaruh terhadap manajemen laba. Hal ini dikarenakan komite audit merupakan salah satu mekanisme Corporate Governance tidak mampu memberikan hasil evaluasi terhadap manajemen yang berkualitas kepada dewan komisaris. Dewan direksi tidak berpengaruh terhadap manajemen laba. Hal ini dikarenakan dewan direksi tidak sepenuhnya bertanggung jawab dalam pengelolaan dan anggaran dasar perusahaan. Pendidikan manajer tidak berpengaruh terhadap manajemen laba. Hal ini dikarenakan banyaknya latar belakang pendidikan yang berbeda sehingga dasar pengetahuan manajer tentang laporan keuangan pun bervariasi. Ukuran perusahaan tidak berpengaruh terhadap manajemen laba. Hal ini dikarenakan dengan total asset yang tinggi akan lebih mendapatkan perhatian dari pemerintah maka kemungkinan kecil perusahaan industri dasar dan kimia melakukan manajemen laba untuk melakukan manipulasi laporan keuangannya.

\section{REFERENSI:}

Abbadi, Sinan S.; Hijazi, Qutaiba F.; \&Al-Rahahleh, Ayat S., 2016. Corporate Governance Quality and Earnings Management: Evidence from Jordan, Australasian Accounting, Business and Finance Journal, 10(2), 5475 .

Amperaningrum, I., \& Sari, I.K. 2013. Pengaruh Good Corporate Governance, Leverage, Dan Kinerja Keuangan Terhadap Manajemen Laba (Studi Kasus Pada Perusahaan Perbankan Yang Terdaftar Di Bursa Efek Indonesia). Proceeding PESAT (Psikologi, Ekonomi, Sastra, Arsitektur \& Teknik Sipil). 5, 294-302

Dewi, E.R., \& Khoiruddin. M., 2016. Pengaruh Good Corporate Governance Terhadap Manajemen Laba Pada Perusahaan Yang Masuk Jakarta Islamic Index Tahun 2012-2013. Management Analysis Journal 5(3), 156166 
Gunawan, I K., Darmawan, N. A. S., \& Purwanti, I. G. A. 2015. Pengaruh Ukuran Perusahaan, Profitabilitas, dan Leverage terhadap Manajemen Laba pada Perusahaan Manufaktur yang Terdaftar di Bursa Efek Indonesia (BEI). E-Journal S1 Ak Universitas Pendidikan Ganesha Jurusan Akuntansi Program S1, 3(1), 6-10.

Gunawan,I. K., Darmawan, N.A.S., Purnamawati, G.A., 2015. Pengaruh Ukuran Perusahaan, Profitabilitas, Dan Leverage Terhadap Manajemen Laba Pada Perusahaan Manufaktur Yang Terdaftar Di Bursa Efek Indonesia (BEI). E-Journal S1 Ak Universitas Pendidikan Ganesha Jurusan Akuntansi Program S1. 3(1), 1-10

Hidayanti, E., \& Paramita.R. W.D., 2014. Pengaruh Good Corporate Governance Terhadap Praktik Manajemen Laba Riil Pada Perusahaan Manufaktur. Jurnal WIGA, 4(2), 1-16

Ilyas, M., Ahmad. A., Khan, M.T.,Khan I. 2018 The Impact Of Corporate Governance On Earnings Management: Empirical Evidence From Pakistan. Journal of Research in Social Sciences. 6(2), 256-271

Jao,R., Pagalung, G. 2011. Corporate Governance, Ukuran Perusahaan, Dan Leverage Terhadap Manajemen Laba Perusahaan Manufaktur Indonesia. 8(1), 43-54

Khurnanto, R.F., \& Syafruddin.M. 2015. Pengaruh Komite Audit Dan Audit Eksternal Terhadap Manajemen Laba. Diponegoro Journal of Accounting. 4(4), 1-8

Lestari, E., Murtanto. 2017. Pengaruh Efektivitas Dewan Komisaris Dan Komite Audit, Struktur Kepemilikan, Kualitas Audit Terhadap Manajemen Laba. Media Riset Akuntansi, Auditing \& Informasi. 17(2), 97-115

Mariana. A., Susilawati, R.A.E.., \& Purwanto, N. 2016. Pengaruh Good Corporate Governance, Leverage, Dan Ukuran Perusahaan Terhadap Manajemen Laba Perbankan Yang Terdaftar Di Bei. Journal Riset Mahasiswa Akuntansi. 4(1), 1-17

Nasution, Marihot Dan Doddy Setiawan. 2007. Pengaruh Corporate Governance Terhadap Manajemen Laba Di Industri Perbankan Indonesia. Simposium Nasional Akuntansi X Unhas Makasar.

Okougbo, P. O., \& Okike, E. (2015). Corporate Governance and Earnings Management: Empirical Evidence from Nigeria. Corporate Ownership \& Control, 12(4-2), 312-326. Http://Doi.Org/10.22495/Cocv

Oktavian, R.N., Nur. E., Ratnawati, V., 2015. Pengaruh Good Corporate Governance Terhadap Kualitas Laba Dengan Manajemen Laba Sebagai Variabel Intervening. Jurnal SOROT, 10 (1), 1 - 142

Sari, A.A.I.P., I G.A.M. Putri, G.A.M.A.D., 2015. Pengaruh Mekanisme Corporate Governance Pada Manajemen Laba. E-Jurnal Akuntansi Universitas Udayana, 8(1), 94-104

Sulistyanto, H. Sri. 2014. Manajemen Laba. Teori Dan Metode Empiris. Jalarta : Grasindo.

Susanto, Yulius K., Pradipta, A., \& Cecilia, E. 2019. Earnings Management: Esop and Corporate Governance, Academy of Accounting and Financial Studies Journal, 23(Special 1), 1-13 
